\title{
Debt Maturity and the Effects of Growth Opportunities and Liquidity Risk on Leverage: Evidence from Chinese Listed Companies
}

\author{
Sunitha VIJAYAKUMARAN ${ }^{1}$, Ratnam VIJAYAKUMARAN ${ }^{2}$
}

Received: December 20, 2018 Revised: June 18, 2019 Accepted: July 1, 2019

\begin{abstract}
The study examines the effects of growth opportunities, debt maturity and liquidity risk on leverage, making use of a large panel of Chinese listed firms. Research on capital structure has broadened its scope from a single capital structure decision (the debt/equity choice) to various attributes of the debt in firms' capital structure. We use the system Generalized Method of Moments estimator to control for unobserved heterogeneity and the potential endogeneity of regressors. We find a negative relationship between growth opportunities and leverage. Further, we find that while the proportion of short-term debt attenuates the negative effect of growth opportunities on leverage, it negatively affects leverage as predicted by the liquidity risk hypothesis. When we distinguish between state owned firms and private controlled firms, we find evidence that these effects are only relevant to private controlled firms. However, our analysis indicates that the economic implication of liquidity risk effect is much lower for Chinese firms than that observed in the literature for US firms. Our study suggests that these differences can be explained by differences in the institutional environment in which firms operate. This finding related to Diamond's (1991) liquidity risk hypothesis extends our understanding of the relationship between liquidity risk and the debt maturity choice.
\end{abstract}

Keywords: Capital structure, debt maturity, liquidity risk, agency problem, growth opportunities, underinvestment, China.

JEL Classification Code: G32, G30, G10, G18, 016.

\section{Introduction}

Research on capital structure decisions has broadened its scope since the seminal work of Modigliani and Miller (1958). A large body of studies have focused on a single capital structure decision (the debt/equity choice) (e.g. Rajan \& Zigales, 1995; Lemmon, Roberts, \& Zender, 2008; Sun, Ding, Guo, \& Li, 2016). Yet, recently, other strands of theoretical and empirical literature on capital structure decisions have focused on various attributes of the debt in

1 First Author. Senior Lecturer, Department of Commerce, Faculty of Management Studies and Commerce, University of Jaffna, Sri Lanka. Email: sunithav@univ.jfn.ac.Ik

2 Corresponding Author. Senior Lecturer, Department of Financial Management, Faculty of Management Studies and Commerce, University of Jaffna, Sri Lanka [Postal Address: P.O Box 57, Thirunelvely, Jaffna 40000, Sri Lanka] Email: vijayjfn@gmail.com (๑) Copyright: Korean Distribution Science Association (KODISA) This is an Open Access article distributed under the terms of the Creative Commons Atribution NonCommercial License (https://creativecommons.org/licenses/by-nc/4.0/) which permits unrestricted noncommercial use, distribution, and reproduction in any medium, provided the original work is properly cited. firms' capital structure rather than the simple debt-equity choice. One particular attribute that has been widely studied is debt maturity. For example, in his seminal paper, Myers (1977) argues short-term maturity debt can mitigate the suboptimal incentive effects of debt financing, for example the under-investment problem. That is, short-term debt is an important mechanism to attenuate the agency problems arising from conflicts of interest between stockholders and bondholders. Conversely, according to the liquidity risk hypothesis of Diamond (1991, 1993) and Sharpe (1991), firms with high growth opportunities are expected to suffer from liquidity risk problems when they choose too much short-term debt in order to reduce the underinvestment problems. On balance, considering the two opposing effects of short term debt, firms will trade-off the cost of underinvestment problems (i.e. agency cost) against the cost of liquidity risk problems (i.e., bankruptcy cost) in order to reach an optimal maturity structure.

Following Barclay, Marx, and Smith (2003) and Johnson (2003), the importance of modelling the two major components of a firm's capital structure, namely, leverage 
and debt maturity as jointly determined has been wellestablished in the capital structure literature. ${ }^{2}$ Barclay et al. (2003) mainly focus on the joint determination of leverage and maturity, as well as on the effect of growth opportunities on leverage and debt maturity. Johnson (2003) extends this work by empirically testing both predictions that shortmaturity debt can mitigate the negative effect of high growth opportunities on leverage (Myers, 1997; Hart \& Moore, 1995), on the one hand, and it increases liquidity risk (Diamond, 1991, 1993; Sharpe, 1991), on the other. Using a large sample of 20,565 COMPUSTAT firm-year observations over the period 1986 to 1995 , Johnson (2003) finds that although leverage is negatively associated with growth opportunities, shortening debt maturity helps attenuate the negative effect of growth opportunities on leverage. Additionally, he reports a significant negative relationship between short-term debt and leverage, consistent the liquidity risk hypothesis. His study thus provides evidence for both attenuation effects and liquidity risk effects of shortterm debt for US firms. Based on these findings, the author concludes that the use of short-term debt does not completely eliminate the negative effect of growth opportunities on leverage due to the liquidity risk inherent in it, leading to a less than optimal level of total leverage. In other words, when combining both effects together, his results show that the negative direct effect is greater (i.e., increased liquidity risk) than the positive effects (i.e., reduced under investment problem). As a result, the net effect on leverage is negative.

In this study, using a framework similar to Johnson (2003), we extend this literature to China, a largest emerging market with a unique institutional background, by examining how the attenuation and liquidity risk effects of short-debt maturity simultaneously affect leverage. China has a unique institutional environment where state still retains considerable ownership and control not only in business firms but also in banks; bond market is still very small compared to its huge banking scoter; legal system has not well been developed. As discussed in Cai, Fairchild, and Guney (2008) and Firth, Lin and Wong (2008), the opening up of China's economy and the adoption of capital market principles have presented many investment opportunities for its listed firms and thus Chinese investors have higher expectations regarding their future prospects. Furthermore, there is a high level of information asymmetry; Chinese firms are more likely to face asymmetric information problems over their investment opportunities. Furthermore,

\footnotetext{
${ }^{2}$ That is, while the authors include leverage as an endogenous variable on the right-hand side of their debt-maturity equation, they include debt-maturity as an endogenous variable on the right-hand side of the leverage equation.
}

even after considerable development in the commercial bank lending environment in China (Firth et al., 2009; Tsai, Chen, Lin, \& Hung, 2014), short-term debt still accounts for more than $80 \%$ of the total debt of listed firms. China, therefore, provides an interesting context to examine the interaction between growth opportunities, and leverage and maturity choices of firms and the attenuation and liquidity risk effects of short-term debt in an institutional environment that is different from Western countries where these interactions have already been tested. Thus, our study fills an important gap in the literature.

Using a large panel of 7860 non-financial Chinese listed firms over the period 2003 to 2010 , we estimate the full capital structure decisions of firms by estimating leverage and maturity equations simultaneously, applying the system GMM estimator. We find a negative relationship between growth opportunities and leverage and a positive relationship between the proportion of short-term debt and growth opportunities. We also find that while the proportion of short-term debt attenuates the negative effect of growth opportunities on leverage, it increases liquidity risk. However, our analysis indicates that the economic implication of liquidity risk effect is much lower for Chinese firms than that observed in the literature for US firms.

This paper contributes to the existing literature in several ways. First, to the best of our knowledge, our paper is the first to empirically examine whether the short maturity of debt can attenuate the negative effect of growth opportunities on leverage in the context of emerging markets, particularly in China. Second, our study provides a useful extension to Diamond's (1991) liquidity risk theory of debt maturity by show how institutional differences (such as state ownership of firms) influence the liquidity risk faced by the firms. To this end, we split our sample into state and privately controlled firms and test liquidity risk effect of shortterm debt for these firms separately exploiting China's unique institutional environment where state-owned enterprises (SOEs) and non-SOEs co-exist. Our third contribution is methodological. Following Barclay et al. (2003) and Johnson (2003), we treat leverage and debt maturity as jointly endogenous variables. However, unlike these studies, we use the system GMM estimator to control for the presence of potential endogeneity of all regressors. This is important considering that, for example, a vast number of studies show profitability as an important determinant of leverage, whilst others show that leverage itself affect profitability (e.g. Margaritis \& Psillaki, 2010; Vijayakumaran \& Vijayakumaran, 2019). Furthermore, for the first time, we provide empirical evidence on the attenuation effect of short-term debt in a dynamic framework. The studies by Barclay et al. (2003), Johnson (2003) and Billett, King and Mauer (2007) are in fact based on a static 
framework and, thus fail to shed light on the dynamic nature of firms' capital structure and to control for persistency in the capital structure decisions

The reminder of the paper is organized as follows. Section 2 discusses the relevant theories, and reviews the related empirical studies. In section 3 , we develop testable hypotheses. In Section 4 we discuss the research methodology used to analyse the data. Section 5 describes our data and presents some descriptive statistics. Section 6 discusses our main empirical results. Section 7 provides conclusions.

\section{Literature Review}

We focus on two major relevant theories which are used to explain the rationale behind the use of debt maturity in the capital structure, namely, the agency theory and liquidity risk hypothesis. As Jensen and Meckling (1976) and Myers (1977) argue, when firm's investment opportunities are financed by risky debt, the benefits from undertaking positive NPV projects accrue, at least partially, to the creditors rather than accruing fully to the shareholders. For example, if firms are, in some circumstances, likely to go bankrupt in the near future, equity holders do not have the incentive to contribute new capital because bondholders may capture a large portion of the returns if firms undertake profitable investment projects (the debt overhang problem). In this situation, firms' mangers have the incentive to forego positive net present value project. This is known as the underinvestment problem. This conflict of interest between shareholders and debt holders over the exercise of growth options creates considerable agency costs to the firms.

Myers (1977) suggests that these sub-optimal incentive effects of debt financing associated with high growth options can be controlled in two ways. The first is using a lower level of leverage in the capital structure. Therefore, firms with greater growth opportunities are likely to use a lower than optimal level of leverage. The second is shortening the maturity of debt. Specifically, he notes that if the debt matures before the investment options expire, gains from profitable investment projects do not accrue to debt holders, eliminating therefore the underinvestment problem. It is, therefore, argued that firms whose investment sets contain more growth opportunities have the incentive to employ a higher proportion of short-term debt. This theory predicts a negative relationship between leverage and growth opportunities, on the one hand, and a positive relationship between growth opportunities and short-term debt, on the other.

Diamond (1991) points out that the optimal debt maturity is reached by trading off between the benefit of short-term debt and liquidity risk. Given the information asymmetry between insiders and lenders, short-term debt helps to reduce borrowing costs when a firm receives good news and the debt is refinanced. Further short-term debt reduces underinvestment problem of growth opportunities as discussed above. However, short-term debt exposes the firm to liquidity risk: if a firm defaults in its obligation, control rents are very high (control of the firm is transferred to creditors) (Diamond, 1991) and refinancing costs also increase (denial of refinancing), (Flannery, 1986). The implications of the liquidity risk argument are twofold. ${ }^{3}$ First, the use of too much short-term debt by firms creates liquidity risk problems, thereby increasing bankruptcy costs (Diamond, 1991, 1993). Therefore, the relationship between growth opportunities and short-term debt is determined by the trade-off between the cost of underinvestment problems (i.e. agency cost) and the cost of liquidity risk problems (i.e. bankruptcy cost). Second, firms with higher leverage attempt to avoid liquidity risk by lengthening their maturity (Diamond, 1991, 1993; Sharpe, 1991; Leland \& Toft, 1996). Thus, the theory predicts a negative relationship between leverage and short-term debt.

\section{Hypotheses}

\subsection{Leverage and Growth Opportunities}

Agency arguments suggest that although debt financing can mitigate conflicts of interest between managers and shareholders, i.e., agency costs of equity, it may create conflicts of interest between shareholders and bondholders, i.e., agency costs of debt (Jensen \& Meckling, 1976; Myers, 1977; Jensen, 1986). Myers (1977) argues that when managers in a firm with risky debt outstanding act in the interest of equity holders to maximize the value of equity rather than total firm value, they have incentives to suboptimally invest in future growth opportunities.

More specially, Myers (1977) argues that managers of highly levered firms may be induced to reject positive net present value projects because a portion of the benefits of the project would accrue to debt holders. The loss in firm value from these suboptimal investment decisions and the cost of contracting mechanisms (e.g. short-term debt or debt covenants) that the firm uses to mitigate stockholderbondholder conflicts account for considerable agency cost of debt. In the absence of mechanisms to control these

\footnotetext{
${ }^{3}$ Liquidity risk is a financial risk that a firm may be unable to meet short term financial demands. This usually arises from the difficulty or the inability to convert a security or hard asset to cash.
} 
conflicts between stockholders and bondholders, rational bond holders anticipate conflicts and thus require a higher premium for debt financing. Therefore, in order to mitigate or avoid potential conflicts over the exercise of future growth options altogether, the firm may resort to using less debt financing. Thus, agency arguments predict that there should be a negative relationship between growth opportunities and leverage. A large number of empirical studies provide empirical support for this theoretical prediction (Rajan \& Zigales, 1995; Florackis \& Ozkan, 2009, Sun et al., 2016). Using data from Chinese listed firms, Zou and Xiao (2006) and Moosa, Li, and Naughton (2011) find a negative relationship between leverage and growth opportunities, suggesting that Chinese listed firms with high growth options are likely to face conflicts of interest between shareholders and debtholders. In line with these findings, we hypothesize that:

$\mathbf{H 1}$ : There is a significant negative relationship between leverage and growth opportunities (in the leverage equation)

\subsection{Debt Maturity and Growth Opportunities}

Myers (1977) shows that conflicts between stockholder and bondholders over the exercise of growth opportunities can be controlled for by the use of a shorter maturity of debt in the capital structure. Thus, his theory suggests a positive relationship between growth opportunities and the proportion of short-term debt in total debt. Childs, Mauer, and Ott (2005) also show that short-term debt can mitigate the sub-optimal investment effects of debt financing, by making the debt less sensitive to changes in firm value and by allowing for more frequent re-pricing of debt. A positive relationship between growth opportunities and the use of short-term debt (or equivalently, a negative relationship between growth opportunities and longer maturity) has been observed in several empirical studies (e.g. Barclay et al., 2003; Datta, Iskandar, \& Raman, 2005; Stephan, Talavera, \& Tsapin, 2011). Yet, only a handful of papers have examined attenuation effect of short-term debt. Johnson (2003) argues and provides empirical evidence suggesting that while growth opportunities have a negative direct effect on leverage, the use of short-term debt attenuates this negative effect. Stephan et al. (2011) confirm Johnson's (2003) findings by using a sub-sample of non-investment grade firms. In this line, we hypothesise that:

$\mathbf{H}_{2}$ : There is a significant positive relationship between leverage and growth opportunities interacted with short-term debt (in the leverage equation).
$\mathbf{H}_{3}$ : There is a significant positive relationship between growth opportunities and the proportion of short-term debt (in the maturity equation)

\subsection{Debt Maturity and Liquidity Risk}

According to the liquidity risk hypothesis, firms with higher leverage ratio tend to choose longer maturity of their debt in order to avoid liquidity risk problems (Diamond, 1991, 1993; Sharpe, 1991). Therefore, the theory predicts a negative relationship between leverage and the proportion of shortterm debt in total debt. Most of the previous empirical studies from developed and developing countries (e.g. Datta et al., 2005; Antoniou, Guney, \& Paudyal, 2006; Stephan et al., 2011) report a positive relationship between leverage and long-term debt (equivalently, a negative relationship between the proportion of short-term debt and leverage). In the context of China, prior research reports evidence that Chinese firms largely rely on short-term debt for their external financing needs (Cai et al., 2008; Du, Guariglia, \& Newman, 2015) and that these firms face rollover risk/ liquidity risk. The previous literature interprets the negative relationship between leverage and the proportion of shortterm debt as firms face liquidity risk. We thus hypothesize that:

$\mathbf{H}_{4}$ : There is a significant negative relationship between leverage and the proportion of short-term debt (in both leverage and maturity equations)

\section{Baseline Specifications and Estimation Methodology}

\subsection{Baseline Specifications}

Following Barclay et al. (2003) and Johnson (2003), we estimate two models namely a leverage equation and a maturity equation.

\subsubsection{Leverage Equation}

$$
\begin{aligned}
\text { tlev }_{\mathrm{it}}= & \beta_{0}+\left(\beta_{1} \text { tlev }_{\mathrm{it}-1}\right)+\beta_{2} \text { prop_stlev } \\
\text { it } & +\beta_{3} \text { growth }_{\mathrm{it}} \\
& +\left(\beta_{4} \text { growth }_{\mathrm{it}}{ }^{*} \text { prop_stlev }_{\mathrm{it}}\right)+\beta_{5} \text { tang }_{\mathrm{it}} \\
& +\beta_{6} \text { profit }_{\mathrm{it}}+\beta_{7} \text { size }_{\mathrm{it}}+\beta_{8} \mathrm{vol}_{\mathrm{it}}+\beta_{9} \text { nontaxshd }_{\mathrm{it}} \\
& +\beta_{10} \text { firmage }_{\mathrm{it}}+v_{i}+v_{t}+v_{j}+v_{k}+e_{i t}
\end{aligned}
$$

where i indexes firms, and t years. The terms $v_{i}, v_{t,}, v_{j}$, and $v_{k}$ represent respectively a time-invariant firm specific fixed effect, a time-specific effect, an industry-specific effect, and a region-specific effect. $e_{i t}$ is a random/ idiosyncratic error term. 
On the left hand side of equation (1), our dependent variable is the leverage ratio of firm $i$ in year $t$ (defined as the ratio of the book value of total debt to the book value of the firm's total assets). On the right hand side, we include a stand-alone measure of debt maturity- the proportion of short term debt in total debt (prop_stlev) and growth opportunities (growth). Following Johnson (2003), we include an interaction term between growth opportunities and the proportion of shortterm debt (growth * prop_stlev) in the leverage equation. The interaction term makes the effect of growth opportunities on leverage conditional on the maturity structure of a firm's leverage, and thus allows testing whether a short debt maturity attenuates the negative relationship between growth opportunities and leverage (attenuation effects). In line with Hypothesis 2, we expect to observe a positive relationship between leverage and this interaction term (growth * prop_stlev).

As in the previous literature, control variables included in the leverage equation are firm size, profitability, tangibility, volatility and non-debt tax shield and firm age. These control variables are motivated mainly by the empirical findings of Berger, Ofek, and Yermack (1997), Barclay et al. (2003), Johnson (2003) and Frank and Goyal (2009), among others. Following Johnson (2003), we exclude firm size squared and asset maturity from the leverage equations because capital structure theories suggest that these variables only influence the debt maturity structure.

Since recent studies emphasize that capital structure decisions are more likely to be highly persistent due to adjustment costs and other market imperfections (e.g. Lemmon et al., 2008; Denis, 2012), we include the lagged dependent variable ( tlev $\left._{\text {it- } 1}\right)$ amongst other right hand side variables to capture the dynamic feedback effects in the capital structure decisions.

\subsubsection{Debt Maturity Equation}

Following Johnson (2003), to test the effects of leverage and other independent variables on the maturity structure of the Chinese listed firms, we estimate the following maturity equation.

$$
\begin{aligned}
\text { prop_stlev }_{\text {it }}= & \beta_{0}+\left(\beta_{1} \text { prop_stlev }_{\text {it- }-1}\right)+\beta_{2} \text { tlev }_{i t}+\beta_{3} \text { growth }_{\text {it }} \\
& +\beta_{4} \text { assetmat }_{i t}+\beta_{5} \text { size }_{i t}+\beta_{6}(\text { size })^{2}{ }_{i t} \\
& +\beta_{7} v_{\text {vol }}+\beta_{8} \text { nontaxshd }_{i t}+\beta_{9} \text { firmage }_{i t} \\
& +v_{i}+v_{t}+v_{j}+v_{k}+e_{i t}
\end{aligned}
$$

where i indexes firms, and t years. The term $v_{i}, v_{t}, v_{j}$, and $v_{k}$ represent respectively time-invariant firm specific fixed effects, time-specific effects, industry effects, and regional effects. $e_{i t}$ is a random/ idiosyncratic error term.
On the left hand side of the maturity equation (Eq.2), our dependent variable is the debt maturity. Following Baum, Dorothea, and Talavera (2007) and Stephan et al. (2011), we define debt maturity as the proportion of total debt that matures within one year. On the right hand side, we include leverage, asset maturity, firm size and its squared term, volatility, non-tax shield and firm age. These variables are motivated by the predictions of theoretical models of debt maturity and the empirical findings of Johnson (2003), among others. In addition, in the maturity equation, unobservable firm-specific fixed effects, firm-invariant timespecific effects, the regional and industry effects are controlled for by including dummy variables.

Research emphasize that debt maturity decisions are more likely to be highly persistent due to the adjustment costs and other market imperfections (e.g. Denis, 2012). We thus extend previous empirical works (e.g. Johnson, 2003) to the context of China by estimating a dynamic maturity equation where we include the lagged short-term debt to control for the dynamic effects of debt maturity. Firm's speed of adjustment towards its target maturity ratio is calculated by one minus the value of the coefficient of lagged dependent variable $\left(1-\beta_{1}\right)$.

\subsection{Estimation Methodology}

Firms' financial policy choices (e.g. the level of debt and the maturity) are likely to be jointly determined as a function of firm characteristics and the contracting environment. For example, Barclay, Marx, and Smith $(1997,2003)$ show that leverage and debt maturity are endogenously chosen complements. Therefore, to account for the endogenous choice of leverage and maturity, we use the system GMM estimator to estimate the models of leverage and maturity. The system GMM estimator estimates the relevant equation both in levels and in first-differences. First-differencing is used to control for unobserved heterogeneity. We use all right-hand side variables except firm age, volatility and the dummy variables lagged twice or more as instruments in the first-differenced equation, and first-differences of these same variables lagged once as instruments in the level equation.

\section{Data and Descriptive Statistics}

In this section, we describe the dataset and sample that is used in our study and provide a discussion on summary statistics and correlation analysis of our variables. 


\subsection{Data and Sample Selection}

Our sample includes all the publicly held firms that have been listed on the Shanghai and Shenzhen stock exchanges over the period of 2003 to 2010. Data are collected from the China Stock Market and Accounting Research database (CSMAR) and Sino-fin. Following the literature, we first delete firms in financial industries since their capital structure is subject to many regulations. We then remove outliers (i.e. extreme observations below the $1^{\text {st }}$ and above the $99^{\text {th }}$ percentile) for all regression variables. Since we lag all the right hand side variables twice or more to obtain suitable instruments in the system GMM, 7860 firm year observations are used in estimation. This sample is an unbalanced panel

\subsection{Summary Statistics}

Table 1 provides summary statistics for the main variables used in this study for the full sample of firms, as well as for state- and privately-controlled firms. The average leverage to total assets ratio (tlev) is 53.4 per cent. We observe that the average proportion of short-term debt to total debt (prop_stlve) is $86 \%$. For the average firm, $86 \%$ of total debt is due within one year, which implies that short-term debt is popular among Chinese firms. The average long-term debt to total debt ratio is only $14 \%$ in China. The substantially low amount of long-term debt reflects the fact that the Chineselisted companies are mainly financed by short-term debt rather than long-term debt.

The mean (median) value of growth opportunities (growth) of our sample firms (measured by Tobin's ratio) is 2.026 (1.62). This may indicate that the average firm (median) has valuable investment opportunities and thus is likely to face potential underinvestment problems. Furthermore, compared to firms controlled by the state, privatelycontrolled firms exhibit higher growth opportunities (growth) measured by Tobin's $Q$ and use more short-term debt suggesting that these firms may face more underinvestment problems, and thus use more short-term debt. On average, non-sate controlled firms use slightly more total leverage than state-controlled firms. This finding is also consistent with Firth et al. (2012) who show that privately controlled firms are able to get more external financing than state controlled firms with the liberalisation and improvement in the governance of China's banking system.

Table 1: Summary statistics

\begin{tabular}{|l|c|c|c|c|c|c|}
\hline \multicolumn{1}{|c|}{ Variable } & Obs. & Mean & Median & Std. Dev. & Min & Max \\
\hline Panel A full sample firms \\
\hline tlev & 7860 & 0.534 & 0.539 & 0.199 & 0.060 & 2.911 \\
\hline stlev & 7860 & 0.860 & 0.922 & 0.156 & 0.344 & 1.000 \\
\hline Itlev & 7860 & 0.140 & 0.078 & 0.156 & 0.000 & 0.656 \\
\hline growth & 7860 & 2.026 & 1.630 & 1.194 & 0.807 & 8.373 \\
\hline
\end{tabular}

\begin{tabular}{|l|c|c|c|c|c|c|}
\hline \multicolumn{7}{|l|}{ Panel B Privately controlled firms } \\
\hline tlev & 2229 & 0.542 & 0.535 & 0.230 & 0.060 & 3.016 \\
\hline stlev & 2229 & 0.875 & 0.937 & 0.150 & 0.346 & 1.000 \\
\hline Itlev & 2227 & 0.125 & 0.063 & 0.151 & 0.000 & 0.654 \\
\hline growth & 2229 & 2.230 & 1.802 & 1.345 & 0.809 & 8.373 \\
\hline Panel B State controlled firms \\
\hline tlev & 5143 & 0.527 & 0.531 & 0.205 & 0.061 & 3.061 \\
\hline stlev & 5143 & 0.850 & 0.911 & 0.163 & 0.344 & 1.000 \\
\hline Itlev & 5142 & 0.151 & 0.089 & 0.163 & 0.000 & 0.656 \\
\hline growth & 5143 & 1.930 & 1.571 & 1.102 & 0.807 & 8.521 \\
\hline
\end{tabular}

Note: Definitions for all variables are provided in Table A1.

Table A1: Definitions of variables

\begin{tabular}{|c|c|c|c|c|}
\hline \multirow[b]{2}{*}{ Variables } & \multirow[b]{2}{*}{ Name } & \multirow[b]{2}{*}{ Measures } & \multicolumn{2}{|c|}{ Expected sign } \\
\hline & & & \begin{tabular}{|l|} 
Leverage \\
equation
\end{tabular} & $\begin{array}{l}\text { Maturity } \\
\text { equation }\end{array}$ \\
\hline Leverage & lev & $\begin{array}{|lll|}\begin{array}{l}\text { Total } \\
\text { assets }\end{array} & \text { debt/ } & \text { total } \\
\end{array}$ & & $-\left(\mathrm{H}_{4}\right)$ \\
\hline $\begin{array}{l}\text { Debt } \\
\text { maturity }\end{array}$ & prop_stlev & $\begin{array}{|lll|}\begin{array}{l}\text { Short-term } \\
\text { total debt }\end{array} & \text { debt } & \\
\end{array}$ & - $\left(\mathrm{H}_{4}\right)$ & \\
\hline \begin{tabular}{|l|} 
Growth \\
opportunities
\end{tabular} & growth & $\begin{array}{l}\text { The ratio of the sum } \\
\text { of the market value } \\
\text { of equity and the } \\
\text { book value of debt to } \\
\text { the book value of } \\
\text { total assets. (the } \\
\text { tradable share price } \\
\text { is used to calculate } \\
\text { the market value of } \\
\text { the non-tradable } \\
\text { equity shares.) }\end{array}$ & - $\left(\mathrm{H}_{1}\right)$ & $+\left(\mathrm{H}_{3}\right)$ \\
\hline \begin{tabular}{l|} 
Growth \\
opportunities \\
* Short-term \\
debt
\end{tabular} & $\begin{array}{l}\text { growth* } \\
\text { prop_stlev }\end{array}$ & & $+\left(\mathrm{H}_{2}\right)$ & \\
\hline $\begin{array}{l}\text { Long-term } \\
\text { debt }\end{array}$ & Itlev & $\begin{array}{l}\text { Long-term debt/ total } \\
\text { debt (1- prop_stlev) }\end{array}$ & & \\
\hline Size & size & $\begin{array}{l}\text { Natural logarithm of } \\
\text { total real assets }\end{array}$ & + & - \\
\hline Size squired & $\operatorname{size}^{2}$ & & & + \\
\hline $\begin{array}{l}\text { Asset } \\
\text { maturity }\end{array}$ & assetmat & $\begin{array}{l}\text { The ratio of total net } \\
\text { fixed assets to } \\
\text { annual depreciation } \\
\text { expense. The total } \\
\text { net fixed assets } \\
\text { include land and } \\
\text { buildings, plant and } \\
\text { machinery, and } \\
\text { other fixed assets. }\end{array}$ & & - \\
\hline Volatility & $\mathrm{vol}$ & $\begin{array}{l}\text { The standard } \\
\text { deviation of the first } \\
\text { differences of firm's } \\
\text { earnings before taxes } \\
\text { and depreciation over } \\
\text { the four years } \\
\text { preceding the sample } \\
\text { year, divided by } \\
\text { average total assets } \\
\text { for that period. }\end{array}$ & - & - \\
\hline
\end{tabular}




\begin{tabular}{|l|l|l|l|l|}
\hline $\begin{array}{l}\text { Non- } \\
\text { taxshield }\end{array}$ & nontaxshd & $\begin{array}{l}\text { Depreciation/ total } \\
\text { assets }\end{array}$ & - & - \\
\hline Firm age & firmage & $\begin{array}{l}\text { Natural loganithm of the } \\
\text { number of years since } \\
\text { the establishment of the } \\
\text { firm. }\end{array}$ & + & - \\
\hline $\begin{array}{l}\text { Industry } \\
\text { dummies }\end{array}$ & $v_{j}$ & $\begin{array}{l}\text { CSMAR B } \\
\text { classification: 5 } \\
\text { industries Utilities, } \\
\text { Properties, } \\
\text { Conglomerates, } \\
\text { Industry, Commerce } \\
\text { (except financial } \\
\text { industries). }\end{array}$ & & \\
\hline $\begin{array}{l}\text { Regional } \\
\text { dummies }\end{array}$ & $v_{k}$ & $\begin{array}{l}\text { Dummies indicating } \\
\text { whether the firm is } \\
\text { located in the Coastal, } \\
\text { Western, or Central } \\
\text { region of China. }\end{array}$ & \\
\hline $\begin{array}{l}\text { Year } \\
\text { dummies }\end{array}$ & $v_{t}$ & $\begin{array}{l}\text { Year dummies for } \\
\text { the years 2004 to } \\
\text { 2010. }\end{array}$ & \\
\hline
\end{tabular}

Notes: ' + ' means that leverage/short-term debt increases with the variables, '-' means that leverage/short-term debt decreases with the variables.

\subsection{Correlation Analysis}

Table 2 reports a matrix of Pearson correlation coefficients between the variables of interest. We observe a significantly negative correlation between growth opportunities and leverage, consistent with Myer's (1977) prediction. Furthermore, growth opportunities exhibit a statistically significant and positive correlation with the proportion of short-term leverage: firms with more growth opportunities have an incentive to choose short-term debt in order to control underinvestment problems (Myers, 1977). Finally, consistent with the liquidity risk hypothesis, the proportion of short-term leverage is negatively correlated with leverage. In general, the above findings from the correlation analysis are consistent with Johnson's (2003) findings for US firms. We next use the multiple regression framework applying the system GMM estimator to test whether and to what extent the empirical relationship between leverage and growth opportunities and liquidity risk of the firms are affected by firms' choices of debt maturity.

Table 2: Pearson correlation matrices

\begin{tabular}{|l|c|c|c|c|}
\hline & tlev & Itlev & prop_stlev & growth \\
\hline tlev & 1.00 & & & \\
\hline Itlev & $0.09^{*}$ & 1.00 & & \\
\hline prop_stlev & $-0.09^{*}$ & $-1.00^{*}$ & 1.00 & \\
\hline growth & $-0.12^{*}$ & $-0.09^{*}$ & $0.09^{*}$ & 1.00 \\
\hline
\end{tabular}

\section{Empirical Results}

The system GMM estimation results are presented in three subsections: the first subsection focuses on results for the leverage equation, the second contains the results for the maturity equation, and the third contains the results of various robustness checks.

\subsection{Leverage Equation Results}

Table 3 reports the system GMM estimation results of leverage equation. As for the validity of the instruments, the $A R(2)$ and Sargan tests generally indicate that our models are correctly specified and that the instruments are generally valid. The estimated coefficients on growth opportunities (growth) $(-0.106)$ is significantly negative, supporting our hypothesis $\mathrm{H}_{1}$, according to which growth opportunities negatively affect leverage. This finding is consistent with Myers' (1977) prediction that high growth firms use less leverage. This finding is also consistent with previous empirical findings for US firms (e.g. Smith \& Watts, 1992; Rajan \& Zingales, 1995; Johnson, 2003) as well as Chinese listed firms (e.g. Zou \& Xiao, 2006; Haung \& Song, 2006; Moosa et al., 2011). In general, this result is also consistent with the notion that Chinese listed firms face underinvestment problem (e.g. Firth et al., 2008).

The effect is economically significant as well: considering that the mean value of leverage is 0.534 , and the standard deviation of growth opportunities is 1.194 for the firms in our sample (as shown in Table 1), a one-standard deviation increase in the growth opportunities reduces leverage by $23.7 \%$ of its mean for the average firm in our sample. Yet, this effect represents only $1 / 3$ of the marginal effect $(69 \%)$ reported by Johnson (2003) for the average US firm. This difference can be explained by the fact that as shown in Table 1, Chinese listed firms' proportion of long term debt to total debt is only about $14 \%$. As it is long term debt which leads to potential underinvestment (debt overhang) problems over the exercise of growth options, it is likely that Chinese listed firms face lower conflicts of interest between shareholders and debtholders than their Western counterparts. Furthermore, Chinese listed firms are made of state controlled (SOEs) and privately controlled firms. Government's socioeconomic objectives might induce soft budget constraints for government controlled firms (Bai \& Xu, 2005; Guariglia, Liu, \& Song, 2011), suggesting that state controlled firms may be able to obtain debt financing irrespective of growth potential. 
Table 3: System GMM estimation results of leverage equations

\begin{tabular}{|c|c|c|}
\hline & Predicted sign & Dynamic models \\
\hline & & (2) \\
\hline \multirow{2}{*}{$t l e v_{i t-1}$} & + & $0.831^{\text {tat }}$ \\
\hline & & $(0.038)$ \\
\hline \multirow[t]{2}{*}{ prop_stlev } & - & $-0.231^{* *}$ \\
\hline & & $(0.100)$ \\
\hline \multirow[t]{2}{*}{ growth } & - & $-0.106^{*+*}$ \\
\hline & & $(0.046)$ \\
\hline \multirow[t]{2}{*}{ growth* prop_stlev } & + & $0.120^{* *}$ \\
\hline & & $(0.049)$ \\
\hline \multicolumn{3}{|l|}{ Control variables: } \\
\hline \multirow[t]{2}{*}{ profit } & - & $-0.789^{* * * t}$ \\
\hline & & $(0.195)$ \\
\hline \multirow[t]{2}{*}{ size } & + & $0.022^{\text {*t+k }}$ \\
\hline & & $(0.007)$ \\
\hline \multirow[t]{2}{*}{ tang } & + & 0.077 \\
\hline & & $(0.076)$ \\
\hline \multirow[t]{2}{*}{ vol } & - & -0.042 \\
\hline & & $(0.095)$ \\
\hline \multirow[t]{2}{*}{ nontaxshd } & - & -0.938 \\
\hline & & $(0.666)$ \\
\hline \multirow[t]{2}{*}{ firmage } & - & -0.003 \\
\hline & & $(0.006)$ \\
\hline Regional dummies & & yes \\
\hline Industry dummies & & yes \\
\hline Year dummies & & yes \\
\hline Firm fixed effects & & yes \\
\hline Observations & & 6679 \\
\hline $\begin{array}{l}\text { Hansen test ( } p \\
\text { values) }\end{array}$ & & 0.283 \\
\hline$m 1$ ( $p$ values) & & 0.000 \\
\hline$m 2$ ( $p$ values) & & 0.331 \\
\hline
\end{tabular}

Notes: Asymptotic standard errors robust to heteroskedasticity are reported in parentheses. For the system GMM regression, $A R 2$ is a test for second-order serial correlation of the differenced residuals, asymptotically distributed as $N(0,1)$ under the null of no serial correlation. The Hansen $J$ test of over-identifying restrictions is distributed as Chi-square under the null of instrument validity. We treat all right-hand side variables except firm age, volatility and dummy variables as potentially endogenous variables. ${ }^{* * *},{ }^{* *}$, and ${ }^{*}$ denote significance levels of $1 \%, 5 \%$, and $10 \%$, respectively. See Table A1 for definitions of all variables.

More importantly, we observe that the estimated coefficient on the interaction term between growth opportunities and the proportion of short-term debt (growth* prop_stlev) is significantly positive at the $5 \%$ level. This result is consistent with our $\mathrm{H} 2$, and suggests that shortterm debt can significantly attenuate the negative effect of growth opportunities on leverage. This result is also consistent with Myers's (1977) second theoretical prediction, and with the empirical finding in Johnson (2003) for US firms. As for growth opportunities, a one standard deviation increase in the proportion of short-term debt increases leverage only by approximately $7 \%$ of its mean through the positive interaction. ${ }^{4}$ The smaller attenuation effect of shortterm debt compared with $30 \%$ increase in leverage reported by Johnson (2003) for the US firms can be attributed to the fact that Chinese listed firms use larger proportion of shortterm debt in their capital structure than their Western counterparts.

Consistent with our hypothesis $\left(\mathrm{H}_{3}\right)$, the coefficient on the stand-alone short-term debt is found to be significantly negative. This finding is consistent with the finding of Johnson (2003), and lends support to the liquidity risk hypothesis (Diamond, 1991, 1993 and Sharpe, 1991) that predicts a negative relationship between short-term debt and leverage.

Interestingly, computing economic significant, we find that Chinese listed firms face a lower liquidity risk than US firms: a one standard deviation increase in their proportion of short-term debt to total debt reduces in fact their leverage ratio only by approximately $7 \%$ of its mean through the negative direct effect. Furthermore, combining the negative effect between the proportion of short-term debt and leverage (due to the liquidity risk) with the positive interaction effect of short-term debt, the results show that the net effect $(7 \%-7 \%=0)$ on leverage is zero. These finding of a smaller liquidity risk effects (negative effect of the proportion of short-term debt on leverage) and a zero net negative effect of short-term maturity debt for average Chinese firms is in marked contrast to the strong effects $(71 \%,(71 \%-30 \%=) 41 \%$, respectively) reported by Johnson (2003) for the average US firm.

Surprisingly, even though Chinese listed firms use a large amount of short-term debt in the capital structure, the rollover /liquidity risk appears to be less important for them. The possible explanation for why liquidity risk may be less of a concern for Chinese listed firms are as follows. First, out of large number of Chinese firms seeking for listing on both Chinese stock exchanges, only a very small number of firms are granted approval to do so after a stringent screening process. Therefore, the listed firms may be considered more profitable and thus less risky by lenders (especially banks). This reasoning is consistent with Johnson (2003) who reports evidence that the

\footnotetext{
${ }^{4}$ Following Johnson (2003), we calculate this marginal effects as follows: the estimated coefficient of the interaction term between growth opportunities and the proportion of short-term debt (0.120) times the standard deviation of short-term debt $(0.156)$ divided by the mean value of leverage (0.535) times the mean value of growth opportunities (2.026).
} 
liquidity risk of short-term debt is not important for rated US firms (firms with bond ratings) in Compustat and is only relevant for lower quality firms (unrated firms).

Second, a complementary explanation to the above is that in China a considerable number of listed firms are still owned and controlled by the government. Since these firms operate with multiple objectives such as socio-economic objectives, it is costly for the government to allow them to fail. Furthermore, the big four Chinese commercial banks in China are still mainly owned and controlled by the government, which are the main lenders to the firms. This suggests thus that soft budget constraints might arise in government controlled listed firms (Bai \& Xu, 2005; Guariglia et al., 2011). Consequently, state controlled firms are able to obtain external funding or extend the maturity of loans more easily than privately controlled firms (Sheshinski \& Lopez-Calva, 1999), which makes liquidity risk less important for them. Further, unlike their Western counterparts, while Chinese private firms rely on personal (or family) connections and personal reputation of entrepreneurs to obtain finance from alternative financing channels (Allen, Qian, Zhang, \& Zhao, 2012), they use social capital building strategies (Du et al., 2013) for accessing or rolling over debt finance ${ }^{5}$.

Turning to the control variables, the estimated coefficients on these variables in the leverage equation show that results are generally consistent with previous capital structure studies. Specifically, the coefficient on the profitability (profit) is significantly negative., Also, firm size (size) has a significantly positive coefficient consistent with the trade-off and agency theories. The coefficient on tangibility (tang) is not significantly related to leverage. The coefficient on volatility $(\mathrm{vol})$ is negative but insignificant. The non-debt tax shield (nontaxshd) attracts a poorly determined coefficient.

Finally, the estimated coefficient on lagged leverage is significantly positive, and equal to 0.83 , indicating that there is a high level of persistency in the capital structure decisions of Chinese listed firms.

\subsection{Debt Maturity Equation Results}

Table 4 presents the system GMM estimation results for maturity equations. Consistent with the negative coefficient on maturity in the leverage equation, the estimated

\footnotetext{
${ }^{5}$ Allen et al. (2012) note that alternative financing channels, such as informal financial intermediaries, internal financing and trade credits, and coalitions of various forms among firms, investors, and local governments are important even for the State and Listed sectors.
}

coefficient on leverage (tlev) is negative but not significant. Further, we observe that the estimated coefficient on growth opportunities is positive though not statistically significant. Previous empirical studies also report an insignificant relationship between a debt maturity measure and growth opportunities in the debt maturity equation. Consistent with our expectation, the coefficient on asset maturity (assetmat) is negative and statistically significant at $5 \%$ level. This indicates that firms in our sample match the maturities of their assets with those of their liabilities in order to reduce the underinvestment problem (Myers, 1977). Thus, maturity matching is an important strategy for firms in China. This result is also consistent with the findings of the previous empirical studies (e.g. Johnson, 2003; Cai et al., 2008; Deesomsak, Paudyal, \& Pescetto, 2009).

Table 4: System GMM estimation results of maturity equations

\begin{tabular}{|c|c|c|}
\hline & Predicted sign & $\begin{array}{c}\text { Dynamic } \\
\text { models }\end{array}$ \\
\hline & & $(2)$ \\
\hline \multirow[t]{2}{*}{ prop_stlev $_{i t-1}$} & + & $0.520^{* * * x}$ \\
\hline & & $(0.040)$ \\
\hline \multirow[t]{2}{*}{ tlev } & - & $-0.062^{* * *}$ \\
\hline & & $(0.031)$ \\
\hline \multirow[t]{2}{*}{ growth } & + & 0.005 \\
\hline & & $(0.006)$ \\
\hline \multirow[t]{2}{*}{ assetmat } & - & $-0.004^{* \star}$ \\
\hline & & $(0.002)$ \\
\hline \multirow[t]{2}{*}{ size } & - & $-0.265^{*}$ \\
\hline & & $(0.150)$ \\
\hline \multirow[t]{2}{*}{$\operatorname{size}^{2}$} & + & $0.008^{*}$ \\
\hline & & $(0.004)$ \\
\hline \multirow[t]{2}{*}{ vol } & - & -0.068 \\
\hline & & $(0.096)$ \\
\hline \multirow[t]{2}{*}{ nontaxshd } & + & 0.637 \\
\hline & & $(0.469)$ \\
\hline \multirow[t]{2}{*}{ firmage } & - & 0.001 \\
\hline & & $(0.007)$ \\
\hline Regional dummies & & yes \\
\hline Industry dummies & & yes \\
\hline Year dummies & & yes \\
\hline Firm fixed effects & & yes \\
\hline Observations & & 6522 \\
\hline Hansen test ( $p$ values) & & 0.286 \\
\hline$m 1$ ( $p$ values) & & 0.000 \\
\hline$m 2$ ( $p$ values) & & 0.100 \\
\hline
\end{tabular}

Notes: See notes to the Table 3

Following Barclay et al. (2003) and Johnson (2003), we use firm size and its square to control for the effect of credit quality in the debt maturity equation. The coefficients of log firm size (size) is significantly negative and its squared term 
$\left(s^{2} e^{2}\right)$ is significantly positive, which is consistent with Diamond's (1991) prediction that larger firms have higher credit quality/lower liquidity risk and thus use more shortterm debt. This result is also consistent with the findings of the previous studies (e.g. Johnson, 2003; Datta et al., 2005). The estimated coefficient on volatility ( $\mathrm{vol})$ is negative, but insignificant. The negative sign suggests that firms with greater volatility may be associated with greater credit risk. Yet, previous empirical studies also report insignificant volatility coefficient (e.g. Johnson, 2003; Cai et al., 2008). The coefficients on non-debt tax-shield (nontaxshd) are not significant at conventional levels, suggesting that non-debt tax-shield does not influence debt maturity choices. This result is consistent with Johnson (2003). Furthermore, we can see that, as expected, firm age (firmage) is negatively related to the proportion of short-term debt in total debt, but is insignificant.

Finally, it is also worth noting that the lagged short-term debt has a significantly positive coefficient, which is about 0.52 in the dynamic specification. This suggests that 48 per cent (1-0.52) of the gap between the last period's short-term debt and this period's target short-term debt is eliminated within a year. Considering that only about $17 \%$ of the gap between last period's leverage and this period's target leverage is eliminated within a year in the leverage equation, firms adjust their target short term leverage at very high speed $(48 \%)$, suggesting that adjustment costs are rather low for short term debt compared to total leverage. Chinese firms seem to adjust their short-term debt approximately three times faster compared to total leverage, in an attempt to reach their target debt maturity. So, firms with potential investment opportunities finance them largely by shorter maturity debt rather than long-term debt.

\subsection{Additional Tests}

In this sub-section, following Johnson (2003), we verify whether our results are robust to using firms with Tobin's $Q>1$. We then provide regression results for results for state and privately controlled firms separately.

\subsubsection{Differentiating Firms According to Their Tobin's Q}

In this section, we investigate Myer's (1977) prediction that potential underinvestment problems should be more severe for firms with valuable growth opportunities. To take this into account, we divide firms into two categories based on Tobin's Q (growth) in order to identify potential underinvestment problems: (1) firms who have Tobin's q greater than one (growth $>1$ ), (2) firms who have Tobin's q equal or less than one (growth $<=1$ ). Table 5 presents the system GMM estimation results of leverage equation for both groups of firms. As can be seen in column 1 of Table 5 , the coefficient for the attenuation effect is positive and statistically significant at the $5 \%$ level only for firms with valuable growth opportunities, suggesting that the attenuation effect reflects a reduction in the underinvestment problems. Moreover, the coefficients associated with the other variables in columns 1 of Table 5 are generally consistent with the main results reported in Table 3.

Looking at the results for the firms with less growth opportunities (growth <=1) in column 2 of Table 5, our hypothesised variables are statistically insignificant at conventional levels, suggesting that the potential underinvestment problem or attenuation and liquidity risk effects of short-term debt are not important for firms with low growth opportunities. These results are consistent with Johnson (2003).

\subsubsection{Estimating Separate Regressions for State and Non-state Firms}

Chinese listed firms can be classified into state controlled (SOEs) and privately/non-state controlled firms. State controlled firms may have different behaviour than privately controlled firms. For example, Firth et al. (2008) report that the negative relationship between leverage and investment is weaker in state controlled firms. Therefore, leverage may be less sensitive to growth opportunities in state controlled firms. By contrast, as shown in the summary statistics, private firms are more likely to have higher growth opportunities and thus may face a greater underinvestment problem. Furthermore, with the government intervention and guarantee, state controlled firms may be able to obtain necessary external finance for investment and/or extend the maturity of the loans more easily than private firms. Therefore, state controlled firms may face a lower liquidity risk than privately controlled firms.

Focusing on the results of leverage equations in column 3 and 4 of Table 5 , we observe that the coefficient for growth opportunities and that of the stand-alone short-term debt are negatively significant at the $5 \%$ level, whereas the coefficient for growth opportunities interacted with the proportion of short-term debt in total debt (attenuation effect) is positive and statistically significant at the $5 \%$ level for privately controlled firms. As for the state controlled firms, although the coefficient on growth opportunities is negatively significant at the $10 \%$ level, the coefficients on the standalone short-term debt and growth opportunities interacted with proportion of short-term debt in total debt are not statistically significant at the conventional levels. These 
Table 5. Robustness checks: Dynamic system GMM estimation results of leverage equations differentiating firms based on their $Q$ value and ownership

\begin{tabular}{|c|c|c|c|c|c|}
\hline & Predicted sign & Firms with $Q>1$ & Firms with $Q<1$ & $\begin{array}{c}\text { Privately } \\
\text { controlled firms }\end{array}$ & $\begin{array}{c}\text { State controlled } \\
\text { firms }\end{array}$ \\
\hline & & (1) & $(2)$ & (3) & (4) \\
\hline \multirow[t]{2}{*}{$t l e v_{i t-1}$} & + & $0.822^{* *+k}$ & $1.041^{*+* x}$ & $0.839^{* * x}$ & $0.853^{* *+x}$ \\
\hline & & $(0.040)$ & $(0.119)$ & $(0.074)$ & $(0.045)$ \\
\hline \multirow[t]{2}{*}{ prop_stlev } & - & $-0.254^{\text {t*t }}$ & -0.028 & $-0.306^{* *}$ & -0.144 \\
\hline & & $(0.119)$ & $(0.197)$ & $(0.145)$ & $(0.099)$ \\
\hline \multirow[t]{2}{*}{ growth } & - & $-0.110^{* *}$ & 0.072 & $-0.090^{* * *}$ & $-0.043^{*}$ \\
\hline & & $(0.055)$ & $(0.141)$ & $(0.038)$ & $(0.025)$ \\
\hline \multirow[t]{2}{*}{ growth* prop_stlev } & + & $0.123^{\text {t*t }}$ & -0.006 & $0.104^{* * *}$ & 0.054 \\
\hline & & $(0.057)$ & $(0.152)$ & $(0.043)$ & $(0.041)$ \\
\hline \multicolumn{6}{|l|}{ Control variables: } \\
\hline \multirow[t]{2}{*}{ profit } & - & $-0.723^{* * *}$ & $-0.952^{\text {**t }}$ & $-0.765^{* \star *}$ & $-0.546^{* * * *}$ \\
\hline & & $(0.253)$ & $(0.412)$ & $(0.189)$ & $(0.149)$ \\
\hline \multirow[t]{2}{*}{ size } & + & $0.020^{*+*+*}$ & 0.035 & $0.038^{*+*}$ & $0.018^{* * *}$ \\
\hline & & $(0.007)$ & $(0.022)$ & $(0.013)$ & $(0.008)$ \\
\hline \multirow[t]{2}{*}{$\operatorname{tang}$} & + & 0.078 & 0.124 & 0.097 & 0.053 \\
\hline & & $(0.078)$ & $(0.163)$ & $(0.072)$ & $(0.061)$ \\
\hline \multirow[t]{2}{*}{$\mathrm{vol}$} & - & -0.005 & -0.385 & -0.006 & -0.048 \\
\hline & & $(0.104)$ & $(0.319)$ & $(0.148)$ & $(0.102)$ \\
\hline \multirow[t]{2}{*}{ nontaxshd } & - & -.997 & .978 & 0.909 & -0.604 \\
\hline & & $(0.736)$ & $(.762)$ & $(0.826)$ & $(0.641)$ \\
\hline \multirow[t]{2}{*}{ firmage } & - & -0.003 & -0.011 & -0.005 & 0.000 \\
\hline & & $(0.006)$ & $(0.015)$ & $(0.013)$ & $(0.007)$ \\
\hline Regional dummies & & yes & yes & yes & yes \\
\hline Industry dummies & & yes & yes & yes & yes \\
\hline Year dummies & & yes & yes & yes & yes \\
\hline Firm fixed effects & & yes & yes & yes & yes \\
\hline Observations & & 5880 & 642 & 1890 & 4248 \\
\hline Hansen test ( $p$ values) & & 0.288 & 0.330 & 0.236 & 0.595 \\
\hline$m 1$ ( $p$ values) & & 0.000 & 0.0890 & 0.000 & 0.000 \\
\hline$m 2$ ( $p$ values) & & 0.239 & 0.361 & 0.137 & 0.106 \\
\hline
\end{tabular}

Notes: See notes to the Table 3

results are consistent with the notion that the attenuation effect and liquidity risk effects are relevant only for non-state controlled firms in the context of Chinese listed firms. Moreover, the coefficients on the other variables in columns 3 of Table 5 are generally consistent with those reported for the full sample in Table.3.

In an unreported the estimation results for maturity equations, we observe that the estimated coefficients for the independent variables in the maturity equation for non-state controlled firms are consistent with those for the full sample reported in Table 4. By contrast, the estimated coefficients for the independent variables except the legged maturity variable for state controlled firms are statistically insignificant at the conventional significant levels.

\section{Conclusions}

In this paper, we investigate the attenuation effect and liquidity risk effect of the short term debt on leverage using a large sample of Chinese non-financial firm-year observations over the period 2003 to 2010.

First, we find that the direct effect of growth opportunities on leverage is negative, suggesting that Chinese listed firms face underinvestment problem due to the conflicts of interest between shareholders and debtholders/lenders. Second, we find a positive relationship between leverage and growth opportunities interacted with measure of short-term debt. This supports the prediction that short-term debt attenuates the negative effect of growth opportunities on leverage. Third, we find that the short debt maturity negatively affects leverage, as predicted by the liquidity risk hypothesis. The 
latter two results therefore suggest that firms with valuable growth opportunities control the underinvestment problem by shortening the maturity of their debt, whilst using less total leverage in order to avoid liquidity risk. In other words, firms trade off the cost of underinvestment problems against the cost of increased liquidity risk when choosing short debt maturity.

Furthermore, we observe that the economic significance of the negative effect of growth opportunities (underinvestment problem) and short maturity (liquidity risk) as well as the positive attenuation effect of short-term debt on leverage are much lower for Chinese listed firms compared to their US counterparts. We explain the observed differences on the grounds of the different institutional environment in which Chinese and US firms operate. More specially, a considerable number of Chinese listed firms are still owned and controlled by government, so these firms may be less responsive to growth opportunities and less likely to face liquidity risk (government ownership may provide an implicit guarantee). By contrast, although private firms face an underinvestment problem and use a higher proportion of short-term debt, they are able to mitigate the rollover risk through family contacts, relationship and personal reputation of the entrepreneurs.

Additional analysis conducted by differentiating the firms according to whether their Tobin's q is greater or lower than one, as well as according to whether they are state controlled (SOEs) or privately controlled provides further evidence to support our main findings and our explanation for the observed differences between Chinese listed firms and their US counterparts. Our study has important policy implication in that it suggest that the importance of attenuation and liquidity risk effects of short-term debt for a firm is dependent on the institutional environment in which it operate.

The main limitation of this research is that since credible rating system in China has not been well developed (Allen et al., 2012), we are unable to see how the importance of attenuation and liquidity risk effects differs between rated and unrated firms.

\section{References}

Aivazian, V. A., Ge, Y., \& Qiu, J. (2005). Can corporatization improve the performance of state-owned enterprises even without privatization? Journal of Corporate Finance, 11, 791- 808. https://doi.org/10.1016/j.jcorpfin.2004.11.001

Antoniou, A., Guney, Y., \& Paudyal, K. (2006). The determinants of debt maturity structure: evidence from France, Germany and the UK. European Financial
Management, 12(2), 161-194. https://doi.org/10.1111/j.1354-7798.2006.00315.x

Allen, F., Qian, J., Zhang, C., \& Zhao, M. (2012). China's financial system, opportunities and challenges (National Bureau of Economic Research Working paper 17828).

Arellano, M., \& Bover, O. (1995). Another look at the instrumental variable estimation of error-components models. Journal of Econometrics, 68(1), 29-51. Retrieved from https://doi.org/10.1016/0304-4076(94)01642-D

Bai, C., \& Xu, L. (2005). Incentives for CEOs with multitasks: Evidence from Chinese state-owned enterprises. Journal of Comparative Economics, 33, 517-539. https://doi.org/10.1016/j.jce.2005.03.013

Barclay, M. J., Marx, L. M., \& Smith, C. W. (1997). Leverage and maturity as strategic complements (Working Paper). Rochester, NY: Simon Business School. Retrieved from https://ssrn.com/abstract=78671

Barclay, M. J., Marx, L. M., \& Smith, C. (2003). The joint determination of leverage and maturity. Journal of Corporate Finance, 9(2), 149-167. https://doi.org/10.1016/S0929-1199(02)00003-2

Baum, F., Dorothea S. D., \& Talavera, O. (2007). The Effects of Short-Term Liabilities on Profitability: A Comparison of German and US Firms (Working Paper). Boston, MA: Boston College Department of Economics.

Berger, P. G., Ofek, E., \& Yermack, D. L. (1997). Managerial entrenchment and capital structure decisions. Journal of Finance, 52, 1411-1438. https://doi.org/10.1111/j.1540-6261.1997.tb01115.x

Billett, M., King, T., \& Mauer, D. (2007). Growth opportunities and the choice of leverage, debt maturity, and covenants. Journal of Finance, 62(2), 697-730. https://doi.org/10.1111/j.1540-6261.2007.01221.x

Blundell, R. W., \& Bond, S. R. (1998). Initial Conditions and moment restrictions in dynamic panel data models. Journal of Econometrics, 87, 115-143. https://doi.org/10.1016/S0304-4076(98)00009-8

Cai, K., Fairchild, R., \& Guney, Y. (2008). Debt maturity structure of Chinese companies. Pacific-Basin Finance Journal, 16(3), 268-297. https://doi.org/10.1016/j.pacfin.2007.06.001

Childs, P. D., Mauer, D. C., \& Ott, S. H. (2005). Interactions of corporate financing and investment decisions: The effects of agency conflicts. Journal of Financial Economics, 76(3), 667-690. https://doi.org/10.1016/j.jfineco.2004.06.012

Datta, S., Iskandar, D. M., \& Raman, K. (2005). Managerial stock ownership and the maturity structure of corporate debt. Journal of Finance, 60(5), 2333-2350. https://doi.org/10.1111/j.1540-6261.2005.00800.x

Deesomsak, R., Paudyal, K., \& Pescetto, G. (2009). Debt maturity structure and the 1997 Asian financial crisis. 
Journal of Financial Management, 19, 26-42. https://doi.org/10.1016/j.mulfin.2008.03.001

Denis, D. J. (2012). The persistent puzzle of corporate structure, current challenges and new directions. The Financial Review, 47, 631-643. https://doi.org/10.1111/j.1540-6288.2012.00347.x

Diamond, D. W. (1991). Debt maturity structure and liquidity risk. The Quarterly Journal of Economics, 106, 709-737. https://doi.org/10.2307/2937924

Diamond, D. W. (1993). Seniority and maturity of debt contracts. Journal of Financial Economics, 33, 341-368. https://doi.org/10.1016/0304-405X(93)90011-Y

Du, J., Guariglia, A., \& Newman, A. (2015). Do Social Capital Building Strategies Influence the Financing Behavior of Chinese Private Small and Medium-Sized Enterprises? Entrepreneurship Theory and Practice, 39(3), 601-631. https://doi.org/10.1111/etap.12051

Firth, M., Lin, C., \& Wong, S. M. (2008). Leverage and investment under a state-owned bank lending environment: Evidence from China. Journal of Corporate Finance, 14(5), 642-653.

Flannery, M. (1986). Asymmetric information and risky debt maturity choice. Journal of Finance, 41(1), 19-37. https://doi.org/10.1111/j.1540-6261.1986.tb04489.x

Florackis, C., \& Ozkan, A. (2009). Managerial incentives and corporate leverage: Evidence from the United Kingdom. Accounting and Finance, 49(3), 531-553. https://doi.org/10.1111/j.1467-629X.2009.00296.x

Frank, M. Z., \& Goyal, V. K. (2003). Testing the pecking order theory of capital structure. Journal of Financial Economics, 67(2), 217-248. https://doi.org/10.1016/S0304-405X(02)00252-0

Guariglia, A., Liu, X., \& Song, L. (2011). Internal finance and growth, Micro econometric evidence on Chinese firms. Journal of Development Economics, 96, 79-94. https://doi.org/10.1016/j.jdeveco.2010.07.003

Guedes, J., \& Opler, T. (1996). The determinants of the maturity of corporate debt issues. Journal of Finance, 51, 1809-1833. https://doi.org/10.1111/j.1540-6261.1996.tb 05227.x

Hart, O., \& Moore, J. (1995). Debt and seniority: An analysis of hard claims in constraining management. American Economic Review, 85, 567-585.

Huang, G., \& Song, F. M. (2006). The determinants of capital structure, evidence from China. China Economic Review, 17, 14-36. https://doi.org/10.1016/j.chieco.2005.02.007

Jensen, M. (1986). Agency costs of free cash flow, corporate finance and takeovers. American Economic Review, 76(2), 323-39. https://www.jstor.org/stable/1818789

Jensen, M., \& Meckling, W. (1976). Theory of the firm, managerial behaviour, agency costs, and capital structure.
Journal of Financial Economics, 3(4), 305-360. https://doi.org/10.1016/0304-405X(76)90026-X

Johnson, S. (2003). Debt maturity and the effects of growth opportunities and liquidity risk on leverage. Review of Financial Studies, 16, 209-236. https://doi.org/10.1093/rfs/16.1.0209

Lemmon, M. L., Roberts, M. R., \& Zender, J. F. (2008). Back to the beginning: persistency and the cross-section of corporate capital structure. Journal of Finance, 63(4), 1575-1608. https://doi.org/10.1111/j.1540-6261.2008. 01369.x

Margaritis, D., \& Psillaki, M. (2010). Capital structure, equity ownership and firm performance. Journal of Banking \& Finance, 34, 621-632. https://doi.org/10.1016/j.jbankfin.2009.08.023

Modigliani, F. F., \& Miller, M. H. (1958). The cost of capital, corporation finance, and the theory of investment. American Economic Review, 48(3), 261-97.

Moosa, I., Li, L., \& Naughton, T. (2011). Robust and fragile firm-specific determinants of the capital structure of Chinese firms. Applied Financial Economics, 1331-1343. https://doi.org/10.1080/09603107.2011.570714

Myers, S. (1977). Determinants of Corporate Borrowing. Journal of Financial Economics, 5, 147-175. https://doi.org/10.1016/0304-405X(77)90015-0

Rajan, R. G., \& Zingales, L. (1995). What Do We Know About Capital Structure Choice? Some Evidence from International Data. Journal of Finance, 50(5), 1421-60. https://doi.org/10.1111/j.1540-6261.1995.tb05184.x

Sharpe, S. A. (1991). Credit rationing, concessionary lending, and debt maturity. Journal of Banking \& Finance, 15(3), 581-604. https://doi.org/10.1016/0378-4266(91) 90087-3

Sheshinski, E., \& López, C. L. F. (2003). Privatization and its benefits: Theory and evidence. CESifo Economic Studies, 49(3), 429-459. https://doi.org/10.1093/cesifo/49.3.429

Smith, J. C. W., \& Watts, R. L. (1992). The investment opportunity set and corporate financing, dividend, and compensation policies. Journal of Financial Economics, 32(3), 263-292. https://doi.org/10.1016/0304405X(92)90029-W

Stephan, A., Talavera, O., \& Tsapin, A. (2011). Corporate debt maturity choice in emerging financial markets. The Quarterly Review of Economics and Finance, 51, 141-151. https://doi.org/10.1016/j.qref.2010.12.003

Stulz, R. (1990). Managerial discretion and optimal financing policies. Journal of Financial Economics, 26, 3-27. https://doi.org/10.1016/0304-405X(90)90011-N

Sun, J., Ding, L., Guo, J. M., \& Li, Y. (2016). Ownership, capital structure and financing decision: evidence from the 
UK. The British Accounting Review, 48(4), 448-463. https://doi.org/10.1016/j.bar.2015.04.001

Tsai, Y. J., Chen, Y. P., Lin, C. L., \& Hung, J. H. (2014). The effect of banking system reform on investment-cash flow sensitivity: Evidence from China. Journal of Banking \& Finance, 46 ,

166-176.
Vijayakumaran, S., \& Vijayakumaran, R. (2019). Leverage, debt maturity, corporate performance: Evidence from Chinese listed companies. Asian Economic and Financial Review, 9(4), 491-506. https://doi.org/10.18488/journal.aefr.2019.94.491.506

Zou, H., \& Xiao, J. Z. (2006). The Financing Behaviour of Listed Chinese Firms. British Accounting Review, 38, 239258. https://doi.org/10.1016/j.bar.2006.04.008 